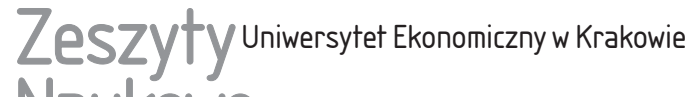 Naukowe
}

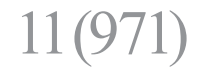

ISSN 1898-6447

Zesz. Nauk. UEK, 2017; 11 (971): 75-94

DOI: 10.15678/ZNUEK.2017.0971.1105

\author{
Urszula Załuska
}

Dorota Kwiatkowska-Ciotucha

\section{Analiza porównawcza sytuacji osób w wieku niemobilnym w krajach Unii Europejskiej}

\section{Streszczenie}

W artykule przedstawiono wyniki badań, których celem była obiektywna ocena sytuacji osób w wieku niemobilnym w krajach Unii Europejskiej (UE 27) i porównanie jej z subiektywnymi odczuciami respondentów ze wskazanej grupy wiekowej. Uwagę zwrócono na sytuację Polski na tle pozostałych krajów członkowskich, a także poszukiwanie dobrych wzorców. W ramach badań porównano dwa podejścia do oceny sytuacji wyróżnionej grupy wiekowej. Pierwsze podejście oparte było na danych obiektywnych obrazujących sytuację w obszarach szczególnie ważnych dla funkcjonowania w społeczeństwie. W drugim podejściu wykorzystano subiektywne oceny satysfakcji osób w wieku 50-64 lat. W badaniu zastosowano metody taksonomiczne. Wyniki badań pozwoliły na wskazanie krajów najbardziej przyjaznych osobom w wieku niemobilnym oraz skonfrontowanie obiektywnie ocenianej i subiektywnie odczuwanej sytuacji tych osób w poszczególnych krajach.

Słowa kluczowe: wielowymiarowa analiza porównawcza, zmienna syntetyczna, miara rozwoju, osoby w wieku niemobilnym.

Klasyfikacja JEL: C19.

Urszula Załuska, Uniwersytet Ekonomiczny we Wrocławiu, Wydział Zarządzania, Informatyki i Finansów, Katedra Logistyki, ul. Komandorska 118-120, 53-345 Wrocław, e-mail: urszula. zaluska@ue.wroc.pl

Dorota Kwiatkowska-Ciotucha, Uniwersytet Ekonomiczny we Wrocławiu, Wydział Zarządzania, Informatyki i Finansów, Katedra Logistyki, ul. Komandorska 118-120, 53-345 Wrocław, e-mail: dorota.kwiatkowska@ue.wroc.pl 


\section{Wprowadzenie}

Starzenie się społeczeństw jest coraz bardziej widoczne w większości krajów Unii Europejskiej. Mediana wieku w krajach Unii (UE 27) w ciągu 23 lat wzrosła z 35,2 roku w 1990 r. do 41,5 roku w 2012 r., dla Polski odpowiednio z 32,2 do 38,4 [Rozwiqzania... 2013, s. 21]. Według stanu na 2012 r. średnio w UE 27 aż $44,1 \%$ populacji w wieku produkcyjnym stanowiły osoby w wieku niemobilnym (45-64 lat), w Polsce odpowiednio 42,5\%. Dodatkowo coraz większy udział w ogóle ludności stanowią osoby w wieku poprodukcyjnym. Zgodnie z długookresowymi prognozami demograficznymi dla Polski następować będzie szybkie pogarszanie się sytuacji w tym zakresie (por. rys. 1).

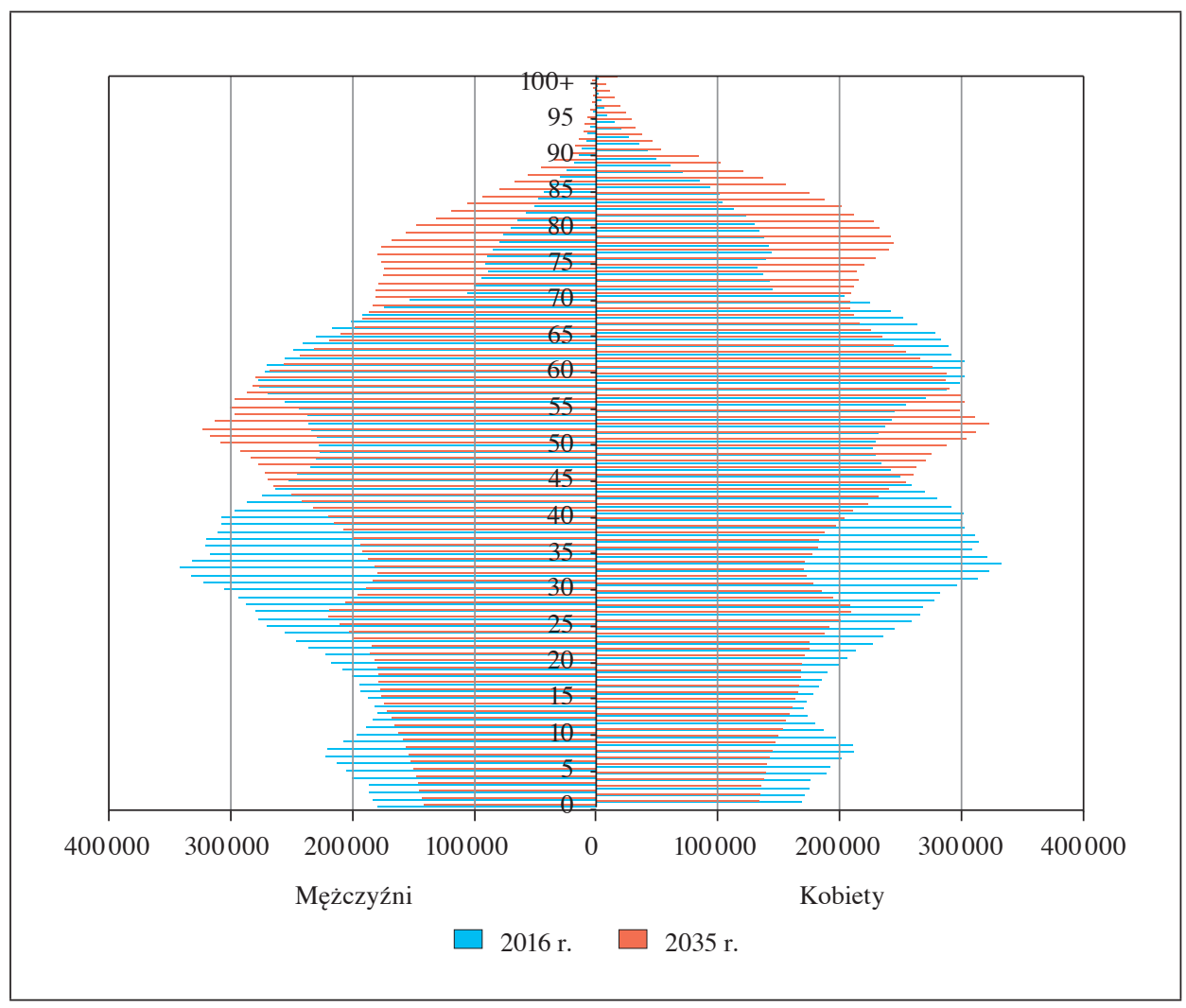

Rys. 1. Piramida wieku - stan w 2016 r. i prognoza na 2035 r.

Źródło: opracowanie własne na podstawie [Prognoza ludności... 2014]. 
Rosnące znaczenie dla gospodarek krajów Unii Europejskiej starszych roczników ${ }^{1}$ stało się inspiracją do podjęcia badań dotyczących obiektywnej oceny sytuacji osób w wieku niemobilnym w krajach członkowskich i porównania jej z subiektywnymi odczuciami respondentów ze wskazanej grupy wiekowej. Ze względu na dostępne przekroje danych analizę przeprowadzono głównie w odniesieniu do osób w wieku 50-64 lat. Zwrócono uwagę na sytuację Polski na tle pozostałych krajów członkowskich, a także poszukiwanie dobrych wzorców. $\mathrm{W}$ artykule przedstawiono wyniki badań porównujących dwa podejścia do oceny sytuacji wskazanej grupy wiekowej. Pierwsze podejście opiera się na danych obiektywnych obrazujących sytuację w obszarach szczególnie ważnych dla funkcjonowania w społeczeństwie, a mianowicie: rynek pracy, sytuacja finansowa, zdrowie i opieka medyczna oraz edukacja i wykorzystanie nowoczesnych technologii. W drugim podejściu wykorzystano subiektywne oceny satysfakcji osób w wieku 50-64 lat. W badaniu zastosowano metody taksonomiczne. Prezentowane wyniki badań zostały uzyskane podczas realizacji projektu dotyczącego problematyki aktywizacji zawodowej i społecznej osób w wieku powyżej 50 lat²

\section{Dane wykorzystane w badaniu}

Analizę przeprowadzono na podstawie najnowszych danych z bazy Eurostat (stan na maj 2017 r.). Do obiektywnej oceny sytuacji osób w wieku niemobilnym w poszczególnych krajach wykorzystano 12 zmiennych charakteryzujących cztery obszary funkcjonowania człowieka: rynek pracy, sytuację finansową, zdrowie i opiekę medyczną oraz edukację i wykorzystanie nowoczesnych technologii. W badaniu starano się wykorzystać dane najbardziej adekwatne do opisu wybranej grupy wiekowej. Z uwagi na różny sposób prezentacji dostępnych danych wzięto pod uwagę dane odnoszące się do grupy osób w wieku 50-64 lat, 45-64 lat, 55-64 lat lub 50-59 lat. Badanie zostało skonstruowane w taki sposób, aby zagwarantować porównywalność danych dla wszystkich krajów Unii Europejskiej. Do opisu poszczególnych obszarów wykorzystano następujące zmienne (zmienne miały charakter stymulanty $S-7$ zmiennych lub destymulanty ${ }^{3} \mathrm{D}-5$ zmiennych):

${ }^{1}$ Problem starzenia się społeczeństw i znaczenia starszych roczników jest szeroko opisywany w literaturze, por. m.in. [Kołodziejczyk-Olczak 2014, Foster i Walker 2015].

2 Projekt współpracy ponadnarodowej POWR.04.03.00-00-W042/15 pn. Inwestuj w siebie nigdy nie jest na to za późno. Model zwiększania dostępu osób 50+ do różnych form uczenia się przez całe życie.

${ }^{3}$ Stymulanty - zmienne, których wzrost wartości jest pożądany, destymulanty - zmienne, których spadek wartości jest pożądany. Więcej na temat charakteru zmiennych zob. m.in. w: [Strahl 1990, Borys 1978]. 
1) rynek pracy:

$x_{1}$ - wskaźnik zatrudnienia osób w wieku 50-64 lat (lfsa_ergan), dane z 2016 r. $\mathrm{w} \%(\mathrm{~S})$,

$x_{2}$ - stopa bezrobocia osób w wieku 50-64 lat (lfsa_urgaed), dane z 2016 r. $\mathrm{w} \%$ (D),

$x_{3}$ - bezrobocie długotrwałe osób w wieku 50-64 lat (lfsq_upgal), dane z 2016 r. w \% (D);

2) sytuacja finansowa:

$x_{4}$ - stawka godzinowa PPS ${ }^{4}$ osób w wieku 50-59 lat (earn_ses_hourly), dane z 2014 r. (S),

$x_{5}$ - udział osób w wieku 50-64 lat o niskich zarobkach w ogóle zatrudnionych (earn_ses_publa), dane z 2014 r. w \% (D);

3) zdrowie i opieka medyczna:

$x_{6}$ - udział osób w wieku 45-64 lat oceniających swój stan zdrowia jako dobry lub bardzo dobry (hlth_silc_02), dane z 2015 r. w \% (S),

$x_{7}$ - udział osób w wieku 45-64 lat mających długotrwałe problemy zdrowotne (hlth_silc_05), dane z 2015 r.w \% (D),

$x_{8}$ - udział osób w wieku 45-64 lat niezadowolonych z opieki medycznej (hlth_silc_08), dane z 2015 r. w \% (D);

4) edukacja i wykorzystanie nowoczesnych technologii:

$x_{9}$ - udział osób w wieku 45-64 lat posiadających wykształcenie wyższe (edat_lfse_03), dane z 2016 r. w \% (S),

$x_{10}$ - udział osób w wieku 55-64 lat uczestniczących w LLL w ostatnich 4 tygodniach (trng_lfse_01), dane z 2016 r. w \% (S),

$x_{11}$ - udział osób w wieku 55-64 lat korzystających z komputera w okresie ostatnich 12 miesięcy (isoc_ci_cfp_cu), dane z 2015 r. w \% (S),

$x_{12}-$ udział osób w wieku 55-64 lat korzystających z Internetu w okresie ostatnich 3 miesięcy (isoc_ci_ifp_iu), dane z 2016 r. w \% (S).

Wartości zmiennych cząstkowych podano w tabeli 1. Wszystkie zmienne różnicują badaną zbiorowość (współczynniki zmienności powyżej 10\%); największym zróżnicowaniem wartości charakteryzuje się zmienna $x_{8}$ - udział osób niezadowolonych z opieki medycznej (102\%), najmniejszym zmienna $x_{1}$ - wskaźnik zatrudnienia (13\%). Warto podkreślić, że w każdym badanym obszarze przynajmniej jedna zmienna ma bardzo silne własności różnicujące (współczynniki zmienności powyżej 50\%).

${ }^{4}$ Standard siły nabywczej (PPS) jest sztuczną jednostką walutową. PPS uzyskiwane jest przez podzielenie każdego agregatu gospodarczego kraju w walucie krajowej przez jego odpowiednik w parytetach siły nabywczej. 


\begin{tabular}{|c|c|c|c|c|c|c|c|c|c|c|c|c|c|c|c|c|c|c|c|}
\hline$x^{9}$ & $\mathbb{N}$ & $\stackrel{\infty}{\sim}$ & ले & f & oิ & ๖ & $\stackrel{\circ}{\circ}$ & ন & $\stackrel{2}{2}$ & F & $\sqrt{6}$ & å & $\hat{6}$ & in & $\curvearrowleft$ & రి & in & \& & 으 \\
\hline$\nLeftarrow=$ & $\mathbb{N}$ & $尺$ & $\stackrel{\infty}{\infty}$ & $\mathscr{F}$ & $\stackrel{R}{R}$ & ฉ & $\stackrel{\infty}{\sim}$ & ন & 文 & $F$ & in & สু & $\tilde{6}$ & in & ลे & ஜ & $\widehat{6}$ & $\mathscr{\infty}$ & 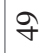 \\
\hline 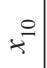 & $\stackrel{\infty}{\sim}$ & $\begin{array}{l}0 \\
\dot{m}\end{array}$ & $0_{0}^{\circ}$ & $\stackrel{n}{m}$ & $\vec{f}$ & ?े. & 2 & $\begin{array}{l}n \\
6 \\
0\end{array}$ & $\stackrel{0}{\stackrel{\theta}{2}}$ & $\hat{0}$ & $\hat{m}$ & $\widehat{\cong}$ & $\infty$ & ñ & $\stackrel{R}{r}$ & 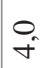 & $\begin{array}{l}0 \\
\text { m }\end{array}$ & $\stackrel{\nabla}{\dot{r}}$ & $\stackrel{0}{-}$ \\
\hline$x^{\circ}$ & $\begin{array}{l}\infty \\
i \\
i\end{array}$ & $\frac{n}{m}$ & $\stackrel{\sim}{\underset{N}{N}}$ & No & $\stackrel{0}{\stackrel{0}{=}}$ & mi & $\begin{array}{l}\hat{b} \\
\text { eे }\end{array}$ & $\hat{\dot{q}}$ & $\begin{array}{l}\infty \\
\sim \\
\sim\end{array}$ & $\begin{array}{l}\infty \\
\stackrel{\sim}{\sim}\end{array}$ & $\begin{array}{l}\dot{\sigma} \\
\stackrel{\infty}{\sim}\end{array}$ & 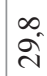 & $\vec{m}$ & $\begin{array}{l}0 \\
\dot{0} \\
\text { n. }\end{array}$ & $\begin{array}{l}0 \\
\text { ñ }\end{array}$ & $\frac{n}{\sim}$ & $\hat{0}$ & $\begin{array}{l}\infty \\
0 \\
0\end{array}$ & $\hat{\sigma}$ \\
\hline$\varkappa^{\infty}$ & $\overrightarrow{0}$ & $\stackrel{\sim}{n}$ & $\begin{array}{l}0 \\
\text { in }\end{array}$ & $\Rightarrow$ & $\hat{o}$ & $\underset{\sigma}{\nabla_{-}}$ & $\overline{ \pm}$ & $\begin{array}{l}\infty \\
\infty\end{array}$ & 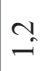 & $\stackrel{\infty}{\Omega}$ & 0 & $\overrightarrow{0}$ & $\stackrel{n}{m}$ & $\stackrel{\dot{r}}{\dot{m}}$ & $\stackrel{\nabla_{n}}{-}$ & $\stackrel{?}{2}$ & $\stackrel{2}{=}$ & 0 & a \\
\hline$\Rightarrow$ & $\stackrel{\vec{m}}{\ddot{m}}$ & $\overrightarrow{\mathrm{d}}$ & त̃ & $\begin{array}{l}\infty \\
\stackrel{f}{f}\end{array}$ & $\begin{array}{l}\infty \\
\text { लि }\end{array}$ & $\stackrel{\vec{m}}{\text { mे }}$ & $\hat{n}$ & $\frac{0}{i n}$ & $\stackrel{\tilde{y}}{\stackrel{y}{~}}$ & $\overline{\mathrm{d}}$ & $\begin{array}{l}\dot{v} \\
\tilde{n}\end{array}$ & $\begin{array}{l}\hat{\sigma} \\
\infty \\
m\end{array}$ & $\begin{array}{l}\text { O. } \\
\text { On }\end{array}$ & $\begin{array}{l}0 \\
\text { D. }\end{array}$ & $\begin{array}{l}0 \\
\text { ते }\end{array}$ & $\stackrel{\sim}{f}$ & $\frac{m}{m}$ & 守 & $\begin{array}{l}\text { j } \\
0\end{array}$ \\
\hline
\end{tabular}

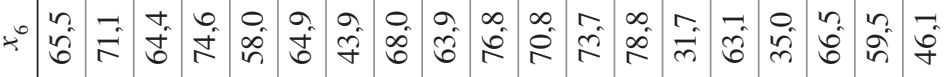

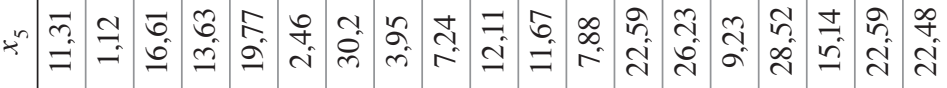

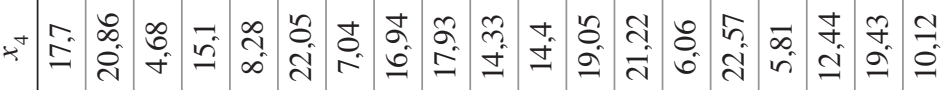

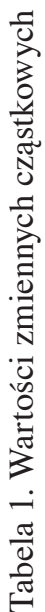

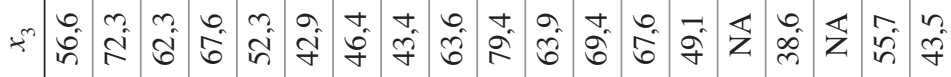

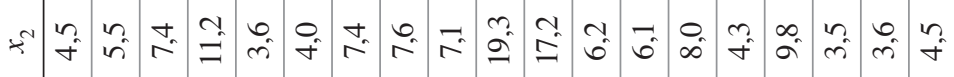

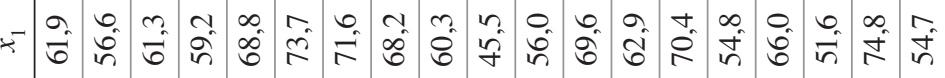

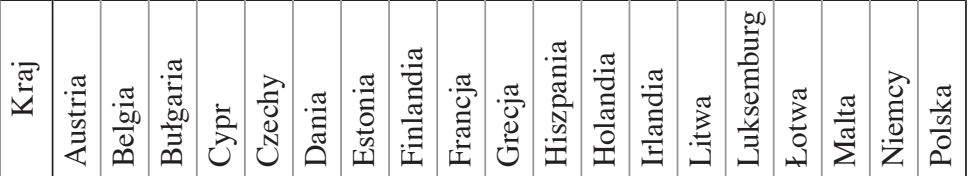




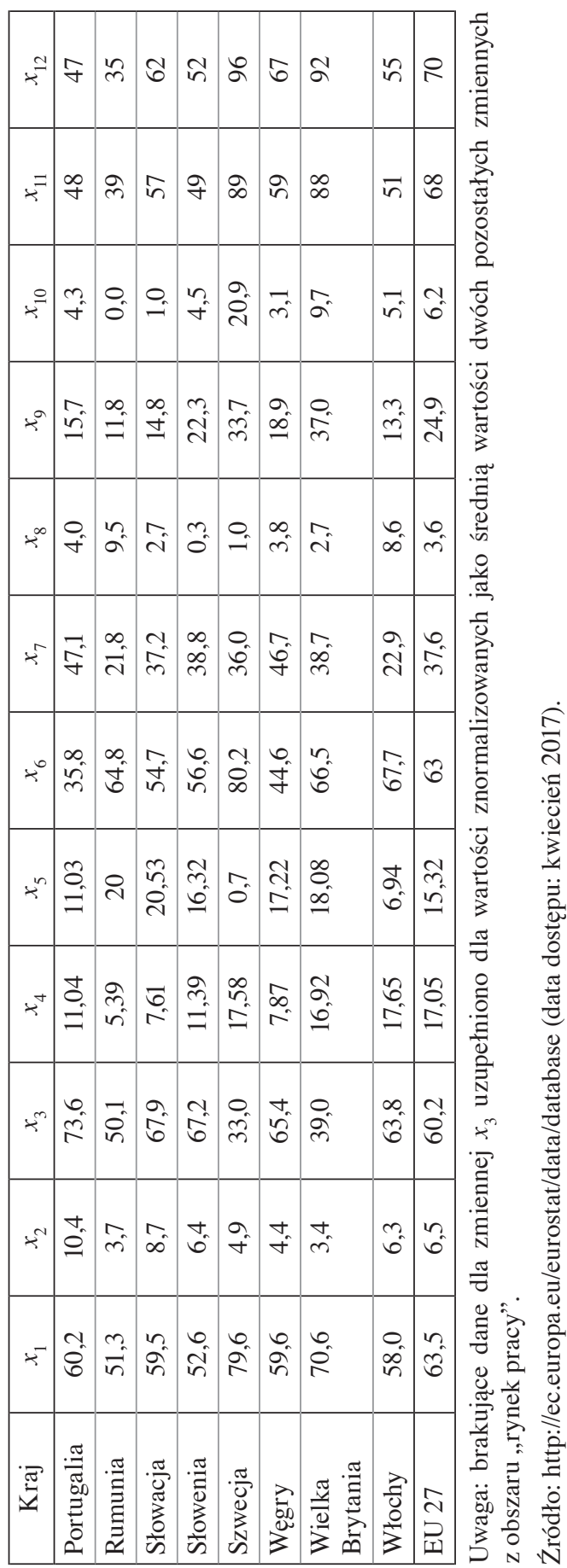


Tabela 2. Różnica między odsetkiem badanych oceniających satysfakcję jako wysoką a odsetkiem badanych oceniających satysfakcję jako niską

\begin{tabular}{|l|c|c|c|c|}
\hline \multicolumn{1}{|c|}{ Kraj } & $y_{1}$ & $y_{2}$ & $y_{3}$ & $y_{4}$ \\
\hline Austria & $-2,4$ & 42,4 & 30,7 & 7,5 \\
\hline Belgia & $-2,1$ & 26,0 & 13,8 & 4,1 \\
\hline Bułgaria & $-77,5$ & $-26,3$ & $-31,7$ & $-41,6$ \\
\hline Cypr & $-51,9$ & 20,2 & 3,9 & $-7,4$ \\
\hline Czechy & $-32,7$ & 23,9 & 7,3 & $-6,1$ \\
\hline Dania & 29,5 & 55,1 & 40,4 & 29,0 \\
\hline Estonia & $-60,0$ & $-1,0$ & 3,4 & $-17,2$ \\
\hline Finlandia & 17,2 & 55,3 & 36,4 & 28,5 \\
\hline Francja & $-18,8$ & 17,0 & 6,7 & 4,2 \\
\hline Grecja & $-62,8$ & $-7,9$ & $-25,6$ & $-25,8$ \\
\hline Hiszpania & $-38,0$ & 8,2 & $-3,0$ & $-12,9$ \\
\hline Holandia & 10,9 & 35,0 & 21,2 & 14,1 \\
\hline Irlandia & $-36,6$ & 41,1 & 14,9 & 4,3 \\
\hline Litwa & $-40,5$ & 10,9 & 13,8 & $-9,7$ \\
\hline Luksemburg & $-2,5$ & 28,8 & 11,9 & 16,3 \\
\hline Łotwa & $-60,7$ & $-15,2$ & 5,7 & $-4,3$ \\
\hline Malta & $-33,1$ & 29,7 & 11,6 & $-5,2$ \\
\hline Niemcy & $-21,8$ & 18,4 & $-3,9$ & $-12,5$ \\
\hline Polska & $-41,2$ & 15,7 & 10,8 & $-1,9$ \\
\hline Portugalia & $-71,8$ & 5,7 & $-4,7$ & $-14,8$ \\
\hline Rumunia & $-24,8$ & 16,2 & $-2,8$ & $-6,9$ \\
\hline Słowacja & $-42,8$ & 27,5 & 2,9 & $-3,8$ \\
\hline Słowenia & $-49,0$ & 17,2 & 6,1 & $-0,4$ \\
\hline Szwecja & 24,7 & 46,8 & 22,7 & $-22,7$ \\
\hline Węgry & $-54,0$ & $-7,7$ & $-1,5$ & $-4,1$ \\
\hline Wielka Brytania & $-17,9$ & 36,1 & 7,6 & $-16,7$ \\
\hline Włochy & $9,9,8$ & 2,5 & \\
\hline & & & & \\
\hline
\end{tabular}

Źródło: http://ec.europa.eu/eurostat/data/database (data dostępu: kwiecień 2017).

Drugie podejście do oceny sytuacji osób w wieku niemobilnym w poszczególnych krajach UE 27 opierało się na wykorzystaniu oceny indywidualnych odczuć satysfakcji przedstawicieli grupy wiekowej 50-64 lat. W badaniu zastosowano zmienną „satysfakcja” (ilc_pw05) z bazy danych Eurostat z 2013 r. (ostatnie ogólnodostępne wyniki badań - stan na maj 2017 r.). Spośród dostęp- 
nych obszarów oceny satysfakcji do badania wybrano cztery wskaźniki cząstkowe:

$y_{1}$ - satysfakcja z sytuacji finansowej,

$y_{2}$ - satysfakcja z warunków mieszkaniowych,

$y_{3}$ - satysfakcja z pracy,

$y_{4}$ - satysfakcja z wykorzystania czasu.

Zmienna „satysfakcja” prezentowana jest w bazie danych Eurostat jako odsetek odpowiedzi na jeden z trzech wariantów oceny satysfakcji: wysoka, średnia, niska. W badaniu uwzględniono różnice między odsetkiem odpowiedzi osób oceniających satysfakcję jako wysoką a odsetkiem odpowiedzi osób oceniających satysfakcję jako niską. Przyjęto, że jest to najpełniejszy sposób subiektywnej oceny sytuacji w poszczególnych krajach. Uzyskane w wyniku takiego przekształcenia wartości ilustrują bowiem nadwyżkę osób oceniających swoją satysfakcję jako wysoką nad osobami oceniającymi satysfakcję jako niską (wynik dodatni) lub odwrotnie, informują o nadwyżce osób oceniających satysfakcję jako niską w stosunku do osób wysoko usatysfakcjonowanych (wynik ujemny). Dane wykorzystane w badaniu przedstawiono w tabeli 2 .

Analiza danych zawartych w tabeli 2 dostarcza wielu ciekawych spostrzeżeń na temat subiektywnych odczuć osób w wieku 50-64 lat dotyczących ich sytuacji, wśród których warto zwrócić uwagę na co najmniej dwa. Po pierwsze, kraje Unii Europejskiej można podzielić na trzy grupy: nieliczną grupę krajów z przewagą osób usatysfakcjonowanych we wszystkich czterech analizowanych wymiarach satysfakcji (Dania, Finlandia, Holandia, Szwecja), nieliczną grupę krajów z przewagą osób nieusatysfakcjonowanych we wszystkich czterech obszarach (Bułgaria, Grecja, Węgry) oraz bardzo liczną grupę krajów, w których odnotowano przewagę usatysfakcjonowanych lub nieusatysfakcjonowanych osób w poszczególnych obszarach (pozostałe 20 krajów UE). Po drugie, można zaobserwować silną polaryzację odczuć satysfakcji w poszczególnych krajach UE - od osób silnie usatysfakcjonowanych do bardzo silnie nieusatysfakcjonowanych (np. satysfakcja z zarobków: Dania 29,5, Portugalia -71,8, satysfakcja z pracy: Dania 40,4, Bułgaria $-31,7)$. W przypadku Polski odnotowano silne niezadowolenie z zarobków $(-42,1)$ oraz przewagę osób usatysfakcjonowanych z warunków mieszkaniowych i z pracy (odpowiednio 15,7 i 10,8), a także bliską równowagi sytuację w przypadku satysfakcji z wykorzystania czasu $(-1,2)$.

\section{Wyniki badań}

Do badania zróżnicowania sytuacji osób w wieku niemobilnym w poszczególnych krajach Unii Europejskiej wykorzystano metody taksonomiczne, które 
pozwalają na porównywanie obiektów w przestrzeni wielocechowej ${ }^{5}$. Zastosowano dwie metody porządkowania liniowego, a mianowicie metodę zmiennej syntetycznej do oceny sytuacji na podstawie danych obiektywnych oraz metody wzorca rozwoju do oceny sytuacji na podstawie danych subiektywnych. Porządkowanie liniowe zrealizowano więc, opierając się na wartości wskaźników syntetycznych, które pozwoliły uporządkować obiekty pod względem poziomu zjawiska złożonego.

Budując zmienną syntetyczną, kierowano się następującymi postulatami ${ }^{6}$ :

- zmienne cząstkowe wykorzystywane do budowy zmiennej syntetycznej różnicują badaną zbiorowość,

- zmienne cząstkowe nie powielają przenoszonych informacji ${ }^{7}$,

- procedura normalizacyjna zmiennych cząstkowych prowadzi do przekształcenia ich pierwotnych wartości na przedział [0;1],

- wszystkie zmienne cząstkowe mają takie samo znaczenie dla oceny sytuacji osób w wieku niemobilnym,

- zmienna syntetyczna ma charakter stymulanty unormowanej na przedziale $[0 ; 1]$.

Zmienną syntetyczną $Z$ obliczano jako średnią ważoną wartości znormalizowanych zmiennych cząstkowych zgodnie ze wzorem:

$$
Z_{i}=\sum_{j=1}^{m} z_{i j} w_{j}
$$

gdzie:

$Z_{i}$ - wartość zmiennej syntetycznej dla kraju $i$,

$z_{i j}$ - wartość znormalizowanej j-tej zmiennej cząstkowej dla kraju $i$,

$w_{j}$ - waga przypisana $j$-tej zmiennej cząstkowej, $w_{j} \in(0,1), \Sigma w_{j}=1$,

$j$ - numer zmiennej cząstkowej.

Dla zmiennych cząstkowych mających charakter stymulant zastosowano normalizację do maksymalnych wartości zaobserwowanych w próbie:

$$
z=\frac{x_{i j}}{\max _{j} x_{i j}}, \quad \max _{j} x_{i j} \neq 0 .
$$

5 Więcej na temat istoty i zastosowania wielowymiarowej analizy statystycznej m.in. w: [Hellwig 1968, 1981, Borys 1978, Grabiński, Wydymus i Zeliaś 1989, Kurkiewicz, Pociecha i Zając 1991, Gatnar i Walesiak 2004, Grabiński 1992, Walesiak 1996, Panek 2009].

${ }^{6}$ Zob. np. [Kwiatkowska-Ciotucha 2002, Załuska 2002].

7 Warunek niepowielania informacji sprawdzono dla poszczególnych obszarów oceny z wykorzystaniem współczynnika korelacji liniowej Pearsona z arbitralnie przyjętą wartością progową wynoszącą 0,8 . 
Dla destymulant zastosowano normalizację do minimalnych wartości zaobserwowanych w próbie:

$$
z=\frac{\min _{j} x_{i j}}{x_{i j}} .
$$

Do budowy zmiennej syntetycznej zastosowano jednakowe wagi dla zmiennych cząstkowych. Zdecydowano się na najprostszy wariant ważenia zmiennych cząstkowych ze względu na brak przesłanek do stosowania innych rozwiązań. Zmienna syntetyczna ma charakter stymulanty, czyli jej wyższa wartość świadczy o lepszej sytuacji osób w wieku niemobilnym w danym kraju. Kraje porządkowano następnie według wartości zmiennej syntetycznej od najbardziej przyjaznego osobom w wieku niemobilnym (najwyższa wartość zmiennej syntetycznej) do najmniej przyjaznego (najniższa wartość zmiennej syntetycznej).

Na podstawie znormalizowanych wartości zmiennych cząstkowych zostały zbudowane cztery zmienne syntetyczne, osobno dla każdego z obszarów badawczych. W tabeli 3 podano wartości tych zmiennych i wyznaczone na ich podstawie miejsca zajmowane przez kraje w poszczególnych obszarach. Pod względem sytuacji osób w wieku niemobilnym na rynku pracy najkorzystniejsze warunki odnotowano w Wielkiej Brytanii, pod względem sytuacji finansowej - w Szwecji, zdrowia i opieki medycznej - w Holandii, a edukacji i wykorzystania nowoczesnych technologii - w Danii. Na ostatnich miejscach znajdują się odpowiednio: Grecja, Bułgaria, Łotwa i Rumunia. Warto zwrócić uwagę, że są kraje, które we wszystkich obszarach zajmują zbliżone miejsca, jak np. Szwecja (wysokie) czy Słowenia (niskie), są również takie, w których występuje duże zróżnicowanie sytuacji w poszczególnych obszarach (np. Estonia czy Wielka Brytania). Polska w analizowanych obszarach zajęła, odpowiednio, miejsca: 9, 19, 22 i 25, co oznacza, że na tle pozostałych krajów Unii Europejskiej tylko w pierwszym z obszarów (rynek pracy) sytuacja osób w wieku niemobilnym nie jest niekorzystna. Szczególnie należy zwrócić uwagę na obszary „zdrowie i opieka medyczna” oraz ,edukacja i wykorzystanie nowoczesnych technologii”, w przypadku których Polska zajęła jedne z ostatnich miejsc wśród krajów unijnych.

Wartości zmiennych syntetycznych w poszczególnych obszarach posłużyły do wyznaczenia ogólnej zmiennej syntetycznej, która w sposób kompleksowy pozwoliła na ocenę sytuacji osób w wieku niemobilnym w poszczególnych krajach Unii. Ogólna zmienna syntetyczna została obliczona jako średnia arytmetyczna wartości zmiennych syntetycznych dla obszarów; przyjęto, że wszystkie obszary są tak samo ważne dla oceny sytuacji. Uzyskane wartości tej zmiennej oraz wyznaczony na tej podstawie ranking krajów przedstawiono $\mathrm{w}$ tabeli 4 . Pierwsze miejsce $\mathrm{w}$ rankingu (z wartością zmiennej na poziomie 0,822) zajęła Szwecja, ostatnie (z wartością $0,372)$ Portugalia, Polska uplasowała się na 21 miejscu (z wartością 0,428$)$. 


\begin{tabular}{|c|c|c|c|c|c|c|c|c|c|c|c|c|c|c|c|c|c|c|c|}
\hline & 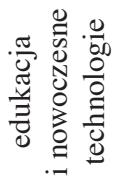 & $=$ & 으 & స̊ & 9 & 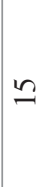 & - & $r$ & $m$ & $\infty$ & $\stackrel{ \pm}{\sim}$ & \pm & $n$ & $\simeq$ & 이 & $0:$ & $\cong$ & $\vec{\sim}$ & $a$ \\
\hline $\begin{array}{l}\ddot{U} \\
.04\end{array}$ & 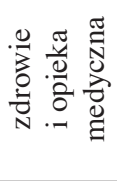 & $N$ & $a$ & 0 & $\cong$ & 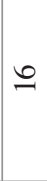 & \pm & $\approx$ & $\vec{\sim}$ & 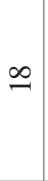 & $m$ & $=$ & $\rightarrow$ & $r$ & $\stackrel{\sim}{\sim}$ & $\circ$ & $\widehat{\imath}$ & $\underline{2}$ & 2 \\
\hline$\Sigma$ & 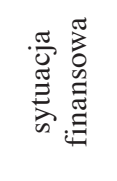 & $=$ & $N$ & $\grave{\lambda}$ & $\cong$ & ㄱ. & $m$ & $\ddot{\sim}$ & $r$ & $a$ & $\cong$ & \pm & 0 & $n$ & $\stackrel{\sim}{\sim}$ & $\nabla$ & $\stackrel{n}{2}$ & 0 & $\infty$ \\
\hline & 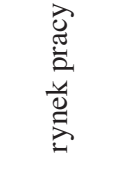 & 으 & $\infty$ & 고 & ন & in & $m$ & $=$ & $\simeq$ & $\vec{\sim}$ & $\widehat{\sim}$ & 이 & ○ & 二 & $\simeq$ & $\infty$ & $\underline{2}$ & 0 & $\nabla$ \\
\hline & 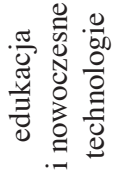 & $\begin{array}{l}\text { శ్ } \\
\text { ర్ } \\
0\end{array}$ & $\begin{array}{l}\hat{\sigma} \\
0 \\
0\end{array}$ & 告 & go & $\frac{m}{n}$ & $\begin{array}{l}\hat{2} \\
\hat{\sigma}\end{array}$ & $\frac{\dot{J}}{\tilde{0}}$ & $\begin{array}{l}\hat{\sigma} \\
\hat{\sigma}\end{array}$ & 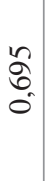 & $\begin{array}{l}n \\
\mathfrak{n} \\
0\end{array}$ & $\begin{array}{l}0 \\
n \\
n \\
o\end{array}$ & $\begin{array}{l}\bar{\delta} \\
\infty \\
0\end{array}$ & $\begin{array}{l}\Re \\
n \\
n \\
0\end{array}$ & $\begin{array}{l}1 \\
\delta \\
n \\
0\end{array}$ & 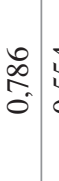 & \begin{tabular}{l}
\multirow{2}{n}{} \\
2 \\
0
\end{tabular} & 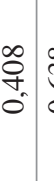 & $\begin{array}{l}\infty \\
\text { రె. } \\
0 \\
0\end{array}$ \\
\hline 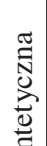 & 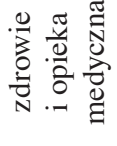 & $\frac{2}{\infty}$ & $\begin{array}{l}0 \\
n \\
n \\
0\end{array}$ & $\begin{array}{l}2 \\
\delta \\
0 \\
0 \\
0\end{array}$ & 守 & مू & $\bar{n}$ & $\begin{array}{l}\vec{\sim} \\
\tilde{2} \\
0\end{array}$ & 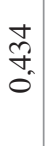 & $\begin{array}{l}t_{0} \\
+ \\
\dot{0}\end{array}$ & 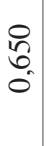 & $\begin{array}{l}n \\
n \\
n \\
0\end{array}$ & \begin{tabular}{c}
0 \\
\multirow{1}{*}{} \\
0 \\
0
\end{tabular} & $\begin{array}{l}2 \\
n \\
0\end{array}$ & 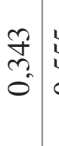 & $\begin{array}{l}n \\
n \\
0 \\
0\end{array}$ & $\begin{array}{c}2 \\
\text { ?े } \\
\text { ?. }\end{array}$ & 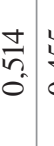 & 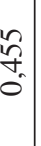 \\
\hline . & 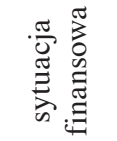 & 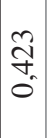 & $\begin{array}{l}n \\
\stackrel{n}{0} \\
0\end{array}$ & $\stackrel{2}{\beth}$ & $\begin{array}{l}8 \\
0 \\
0 \\
0\end{array}$ & స్తి & $\begin{array}{l}\overrightarrow{\tilde{\sigma}} \\
0\end{array}$ & $\begin{array}{l}\infty \\
0 \\
0 \\
0\end{array}$ & \begin{tabular}{l}
$J_{0}$ \\
\multirow{2}{*}{} \\
0
\end{tabular} & $\begin{array}{l}0 \\
\text { J } \\
\text { ó }\end{array}$ & $\begin{array}{l}0 \\
\text { +े } \\
\text { m. } \\
0\end{array}$ & 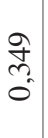 & $\begin{array}{l}0 \\
⿱ \\
+ \\
0 \\
0\end{array}$ & \begin{tabular}{l}
$\stackrel{9}{\infty}$ \\
\multirow{1}{*}{} \\
0
\end{tabular} & \begin{tabular}{c} 
P) \\
\hdashline \\
\end{tabular} & $\begin{array}{l}\infty \\
n \\
n \\
0\end{array}$ & $\begin{array}{c}\vec{\Xi} \\
\overrightarrow{0}\end{array}$ & 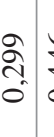 & 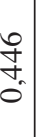 \\
\hline & 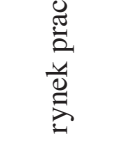 & $\frac{n}{0}$ & $\begin{array}{l}n \\
2 \\
2 \\
0\end{array}$ & $\begin{array}{l}0 \\
\infty \\
2 \\
n \\
0\end{array}$ & $\frac{n}{n}$ & $\begin{array}{l}m \\
\infty \\
0\end{array}$ & $\begin{array}{l}\infty \\
+ \\
\infty \\
0 \\
0\end{array}$ & $\begin{array}{l}\text { \&. } \\
\text { ర్. } \\
0\end{array}$ & $\begin{array}{l}\infty \\
\infty \\
0 \\
0 \\
0\end{array}$ & $\begin{array}{l}n \\
\infty \\
n \\
0\end{array}$ & 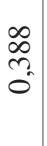 & 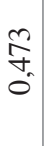 & $\begin{array}{l}\text { గ్ర } \\
\text { O. }\end{array}$ & $\begin{array}{c}\stackrel{1}{\sigma} \\
0\end{array}$ & $\begin{array}{l}\overline{0} \\
\stackrel{0}{0}\end{array}$ & 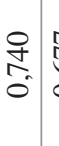 & $\underset{\sigma}{\hat{\sigma}}$ & $\begin{array}{l}0 \\
\infty \\
0 \\
0\end{array}$ & $\begin{array}{l}0 \\
\text { N } \\
0 \\
0 \\
0\end{array}$ \\
\hline & 雨 & 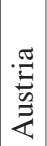 & 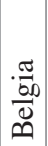 & 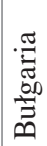 & 芯 & 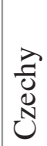 & $\begin{array}{l}\stackrel{\pi}{\Xi} \\
\stackrel{\Xi}{\Xi}\end{array}$ & 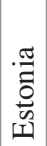 & 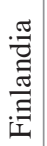 & 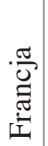 & $\begin{array}{l}\frac{\pi}{8} \\
\stackrel{0}{0} \\
0\end{array}$ & 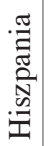 & 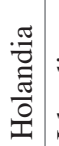 & $\begin{array}{l}\stackrel{\frac{\pi}{3}}{\stackrel{\Xi}{\Xi}} \\
\stackrel{\Xi}{\Xi}\end{array}$ & 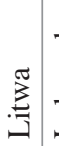 & 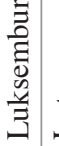 & 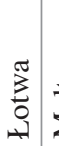 & $\sum_{\frac{\pi}{\pi}}^{\pi}$ & 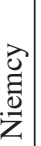 \\
\hline
\end{tabular}




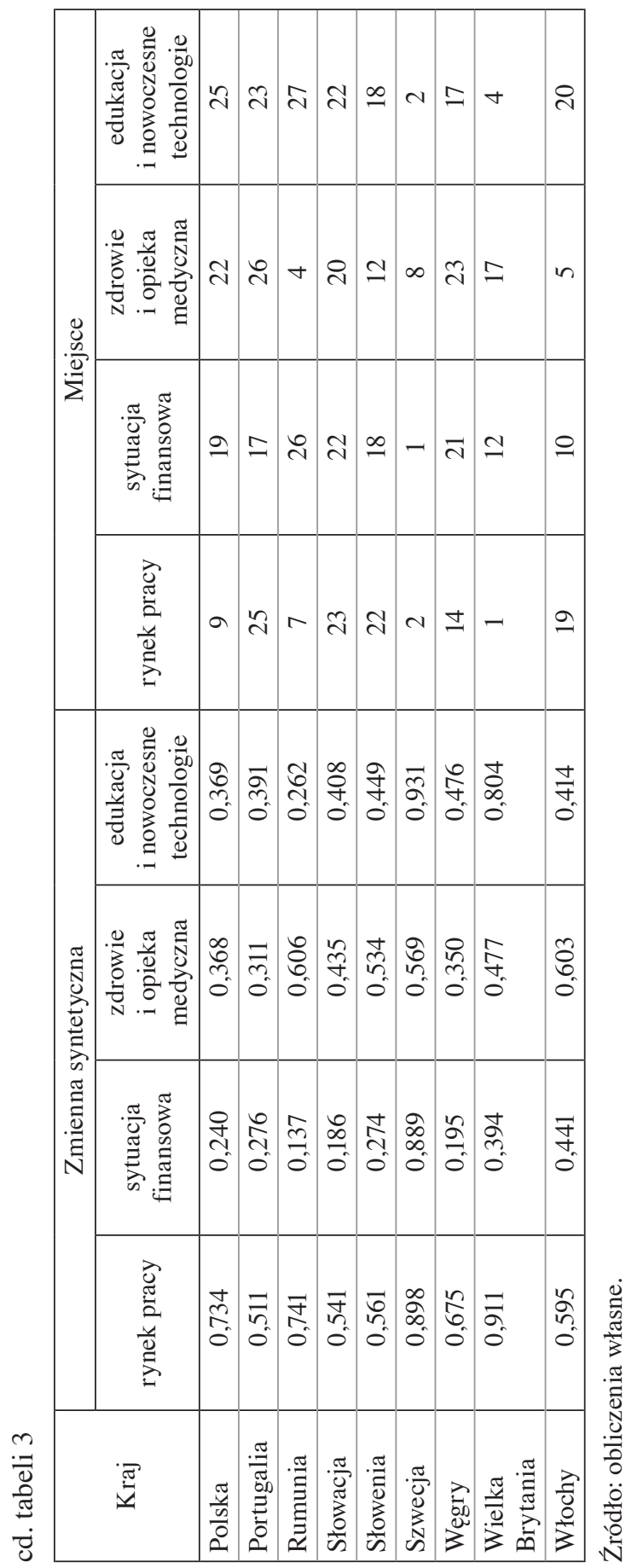


Tabela 4. Ranking krajów według wartości zmiennej syntetycznej

\begin{tabular}{|c|c|c|}
\hline Miejsce & Kraj & $z_{i}$ \\
\hline 1 & Szwecja & 0,822 \\
\hline 2 & Dania & 0,731 \\
\hline 3 & Holandia & 0,682 \\
\hline 4 & Luksemburg & 0,655 \\
\hline 5 & Wielka Brytania & 0,646 \\
\hline 6 & Belgia & 0,640 \\
\hline 7 & Austria & 0,634 \\
\hline 8 & Finlandia & 0,626 \\
\hline 9 & Niemcy & 0,591 \\
\hline 10 & Irlandia & 0,559 \\
\hline 11 & Francja & 0,547 \\
\hline 12 & Włochy & 0,513 \\
\hline 13 & Malta & 0,508 \\
\hline 14 & Czechy & 0,505 \\
\hline 15 & Hiszpania & 0,478 \\
\hline 16 & Estonia & 0,478 \\
\hline 17 & Słowenia & 0,454 \\
\hline 18 & Cypr & 0,454 \\
\hline 19 & Grecja & 0,440 \\
\hline 20 & Rumunia & 0,436 \\
\hline 21 & Polska & 0,428 \\
\hline 22 & Węgry & 0,424 \\
\hline 23 & Łotwa & 0,420 \\
\hline 24 & Bułgaria & 0,415 \\
\hline 25 & Litwa & 0,413 \\
\hline 26 & Słowacja & 0,392 \\
\hline 27 & Portugalia & 0,372 \\
\hline
\end{tabular}

Źródło: obliczenia własne.

W metodzie wzorca rozwoju [Hellwig 1968] wykorzystano znormalizowane (standaryzacja) wartości zmiennych mających charakter stymulant. Postępowano zgodnie z następującymi etapami:

1. Wyznaczono abstrakcyjną obserwację, tzw. wzorzec rozwoju o „najlepszych” wartościach dla każdej zmiennej i tzw. antywzorzec rozwoju o „,najgorszych” wartościach dla każdej zmiennej: 
-wzorzec rozwoju:

$$
\mathbf{z}_{0}=\left[\begin{array}{llll}
z_{01} & z_{02} & \ldots & z_{0 m}
\end{array}\right],
$$

$z_{0 j}=\max _{i} z_{i j}$, gdy zmienna $Z_{j}$ jest stymulantą;

- antywzorzec:

$$
\mathbf{z}_{-0}=\left[z_{-01} z_{-02} \ldots z_{-0 m}\right],
$$

$z_{0 j}=\min _{i} z_{i j}$, gdy zmienna $Z_{j}$ jest stymulantą.

2. Zbadano podobieństwo obserwacji do abstrakcyjnej „,najlepszej” obserwacji przez obliczenie odległości każdej obserwacji od wzorca rozwoju:

$$
d_{i 0}=\sqrt{\sum_{j=1}^{m}\left(z_{i j}-z_{0 j}\right)^{2}}, \quad i=1,2, \ldots, n .
$$

3. Wyznaczono dla każdej obserwacji tzw. miary rozwoju według wzoru:

$$
m_{i}=1-\frac{d_{i 0}}{d_{0}}, \quad i=1,2, \ldots, n,
$$

gdzie:

$m_{i}$ - miara rozwoju dla $i$-tego obiektu,

$d_{0}$ - odległość między wzorcem rozwoju a antywzorcem $d_{0}=\sqrt{\sum_{j=1}^{m}\left(z_{0 j}-z_{-0 j}\right)^{2}}$.

Miara rozwoju jest stymulantą, czyli im wyższy poziom zjawiska złożonego, tym wyższa wartość miary rozwoju.

W tabeli 5 przedstawiono uzyskaną w metodzie wzorca rozwoju macierz odległości między poszczególnymi krajami UE (oznaczenia krajów przyjęte w macierzy: AT - Austria, BE - Belgia, BG - Bułgaria, CY - Cypr, CZ - Czechy, DK - Dania, EE - Estonia, FI - Finlandia, FR - Francja, GR - Grecja, ES Hiszpania, IE - Irlandia, LT - Litwa, LU - Luksemburg, LV - Łotwa, MT - Malta, NL - Holandia, DE - Niemcy, PL - Polska, PT - Portugalia, RO - Rumunia, SK - Słowacja, SI - Słowenia, SE - Szwecja, HU - Węgry, GB - Wielka Brytania, IT - Włochy). Największą odległość odnotowano między Danią i Bułgarią $(8,44)$, najmniejszą, co zaskakujące, między Niemcami i Rumunią $(0,40)$. Polacy pod względem odczuć satysfakcji najbardziej są podobni do Słoweńców $(0,42)$, a najmniej do Bułgarów $(4,44)$.

W tabeli 6 zamieszczono miary rozwoju dla krajów UE oraz stworzony na ich podstawie ranking. Analizując dane zawarte w tabeli, należy zauważyć przede wszystkim rzadko spotykane w badaniach społecznych bardzo duże zróżnicowanie sytuacji w poszczególnych państwach, od bliskiej wzorca sytuacji w Danii $(m=0,999)$ do odpowiadającej pozycji antywzorca sytuacji w Bułgarii $(m=0,000)$. 


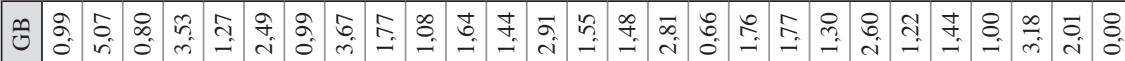

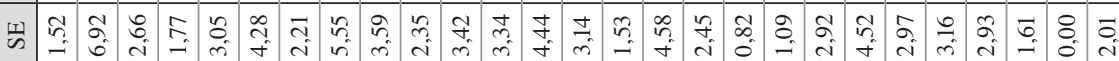

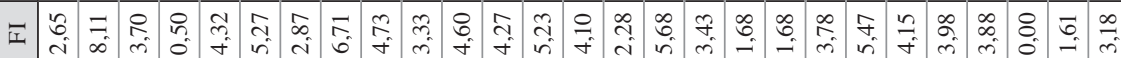

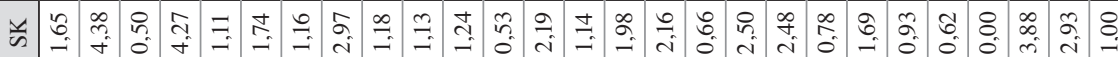

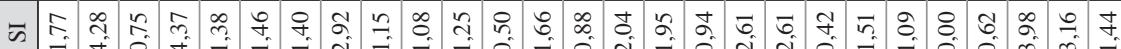

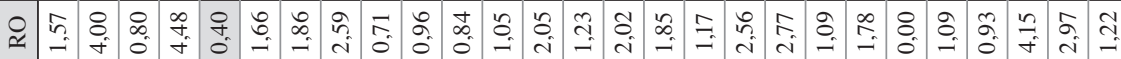

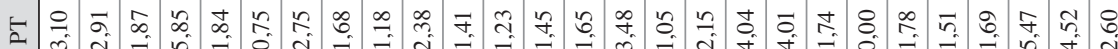

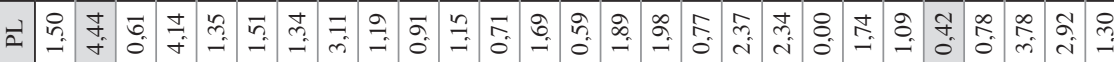

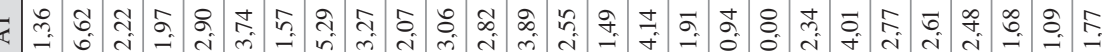

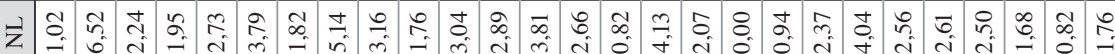
E

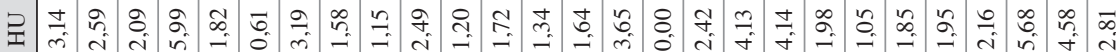

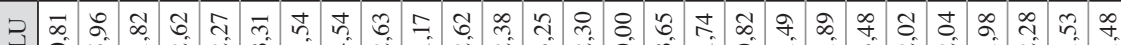

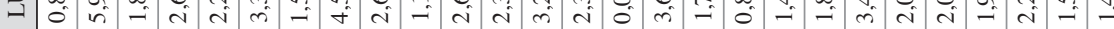

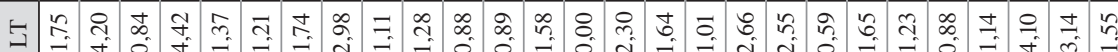

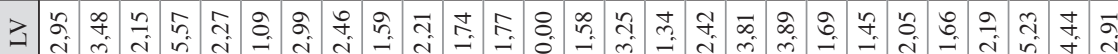

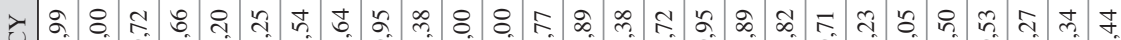

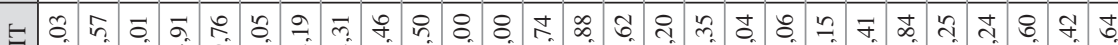
$=$ i

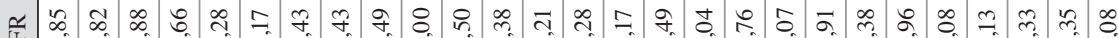

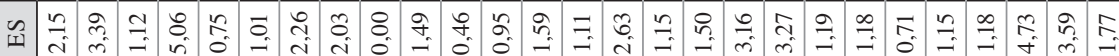

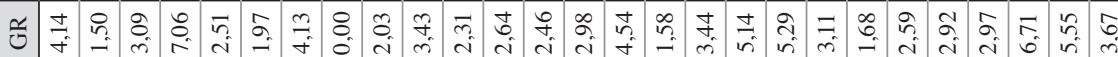

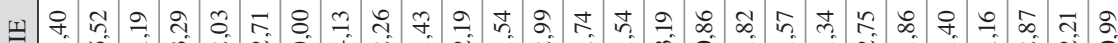
ग

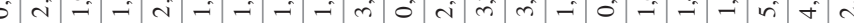

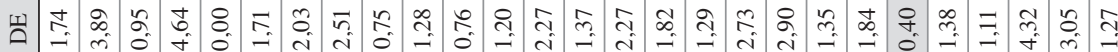

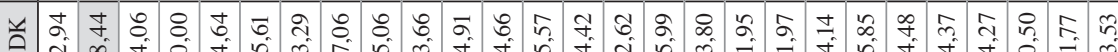

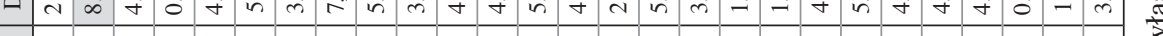

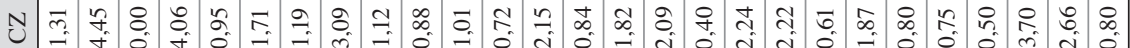
৩ $\bar{n}:$ \&

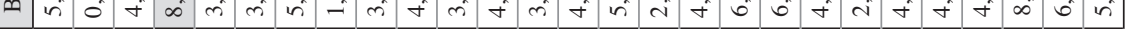

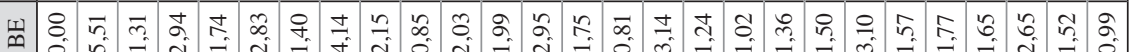

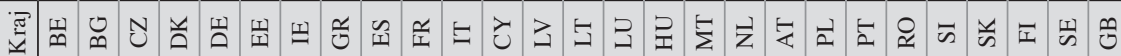


Warto odnotować także dużą różnicę między najlepszymi w rankingu Danią i Finlandią $(0,941)$ a trzecią w kolejności Szwecją $(0,790)$. Należy podkreślić wysokie 13 miejsce Polski, która wyprzedziła w rankingu takie kraje, jak Niemcy, Włochy czy Hiszpania ${ }^{8}$.

Tabela 6. Ranking krajów według wartości miary rozwoju

\begin{tabular}{|c|c|c|}
\hline Miejsce & Kraj & Miara rozwoju \\
\hline 1 & Dania & 0,999 \\
\hline 2 & Finlandia & 0,941 \\
\hline 3 & Szwecja & 0,790 \\
\hline 4 & Holandia & 0,769 \\
\hline 5 & Austria & 0,766 \\
\hline 6 & Luksemburg & 0,689 \\
\hline 7 & Belgia & 0,651 \\
\hline 8 & Irlandia & 0,610 \\
\hline 9 & Wielka Brytania & 0,582 \\
\hline 10 & Francja & 0,566 \\
\hline 11 & Malta & 0,550 \\
\hline 12 & Czechy & 0,519 \\
\hline 13 & Polska & 0,509 \\
\hline 14 & Słowacja & 0,494 \\
\hline 15 & Słowenia & 0,482 \\
\hline 16 & Litwa & 0,476 \\
\hline 17 & Rumunia & 0,469 \\
\hline 18 & Niemcy & 0,451 \\
\hline 19 & Cypr & 0,448 \\
\hline 20 & Włochy & 0,418 \\
\hline 21 & Hiszpania & 0,400 \\
\hline 22 & Łotwa & 0,340 \\
\hline 23 & Estonia & 0,336 \\
\hline 24 & Portugalia & 0,307 \\
\hline 25 & Węgry & 0,290 \\
\hline 26 & Grecja & 0,164 \\
\hline 27 & Bułgaria & 0,000 \\
\hline
\end{tabular}

Źródło: obliczenia własne.

8 Jest to o tyle zaskakujące, że w badaniu odczuć satysfakcji przeprowadzonym w $2006 \mathrm{r}$. z zastosowaniem podobnych zmiennych dla całej populacji, w którym wykorzystano dane dla Polski (Pentorbus) oraz starej Unii Europejskiej (baza ECHP), Polacy oprócz Greków należeli do najbardziej niezadowolonych. Więcej na ten temat w pracy [Kwiatkowska-Ciotucha, Załuska i Dziechciarz 2007]. 


\section{Porównanie wyników dwóch podejść do oceny sytuacji osób w wieku niemobilnym}

W tabeli 7 przedstawiono miejsca zajmowane przez kraje Unii Europejskiej według wartości zmiennej syntetycznej i miary rozwoju. Graficznie porównanie tych wielkości zaprezentowano na rys. 2 .

Tabela 7. Miejsca krajów Unii Europejskiej według wartości zmiennej syntetycznej i miary rozwoju

\begin{tabular}{|c|c|c|}
\hline Kraj & Zmienna syntetyczna & Miara rozwoju \\
\hline Austria & 7 & 5 \\
\hline Belgia & 6 & 7 \\
\hline Bułgaria & 24 & 27 \\
\hline Cypr & 18 & 19 \\
\hline Czechy & 14 & 12 \\
\hline Dania & 2 & 1 \\
\hline Estonia & 16 & 23 \\
\hline Finlandia & 8 & 2 \\
\hline Francja & 11 & 10 \\
\hline Grecja & 19 & 26 \\
\hline Hiszpania & 15 & 21 \\
\hline Holandia & 3 & 4 \\
\hline Irlandia & 10 & 8 \\
\hline Litwa & 25 & 16 \\
\hline Luksemburg & 4 & 6 \\
\hline Łotwa & 23 & 22 \\
\hline Malta & 13 & 11 \\
\hline Niemcy & 9 & 18 \\
\hline Polska & 21 & 13 \\
\hline Portugalia & 27 & 24 \\
\hline Rumunia & 20 & 17 \\
\hline Słowacja & 26 & 14 \\
\hline Słowenia & 17 & 15 \\
\hline Szwecja & 1 & 3 \\
\hline Węgry & 22 & 25 \\
\hline Wielka Brytania & 5 & 9 \\
\hline Włochy & 12 & 20 \\
\hline
\end{tabular}

Źródło: obliczenia własne. 
Analizując miejsca zajmowane przez poszczególne kraje w obu rankingach, można zauważyć, że dla większości krajów lokaty te są zbliżone (np. Belgia odpowiednio 6 i 7 miejsce, Dania 2 i 1, Holandia 3 i 4). Świadczy o tym również wartość współczynnika korelacji rang Spearmana, który wynosi 0,79. Wskazać można jednak kraje, dla których różnice między oboma zajmowanymi miejscami są znaczące. Oznacza to, że subiektywne oceny osób w wieku niemobilnym dotyczące zadowolenia z własnej sytuacji odbiegają od obiektywnych ocen dokonanych na podstawie wartości zmiennej syntetycznej. Wśród krajów, w których niezadowolenie jest wyższe, niż wynikałoby to z obiektywnej oceny, wymienić należy: Niemcy, Estonię, Grecję, Hiszpanię i Włochy. Natomiast do krajów, w których zadowolenie z własnej sytuacji jest wyższe niż obiektywna ocena tej sytuacji, należą: Finlandia, Litwa, Polska i Słowacja.

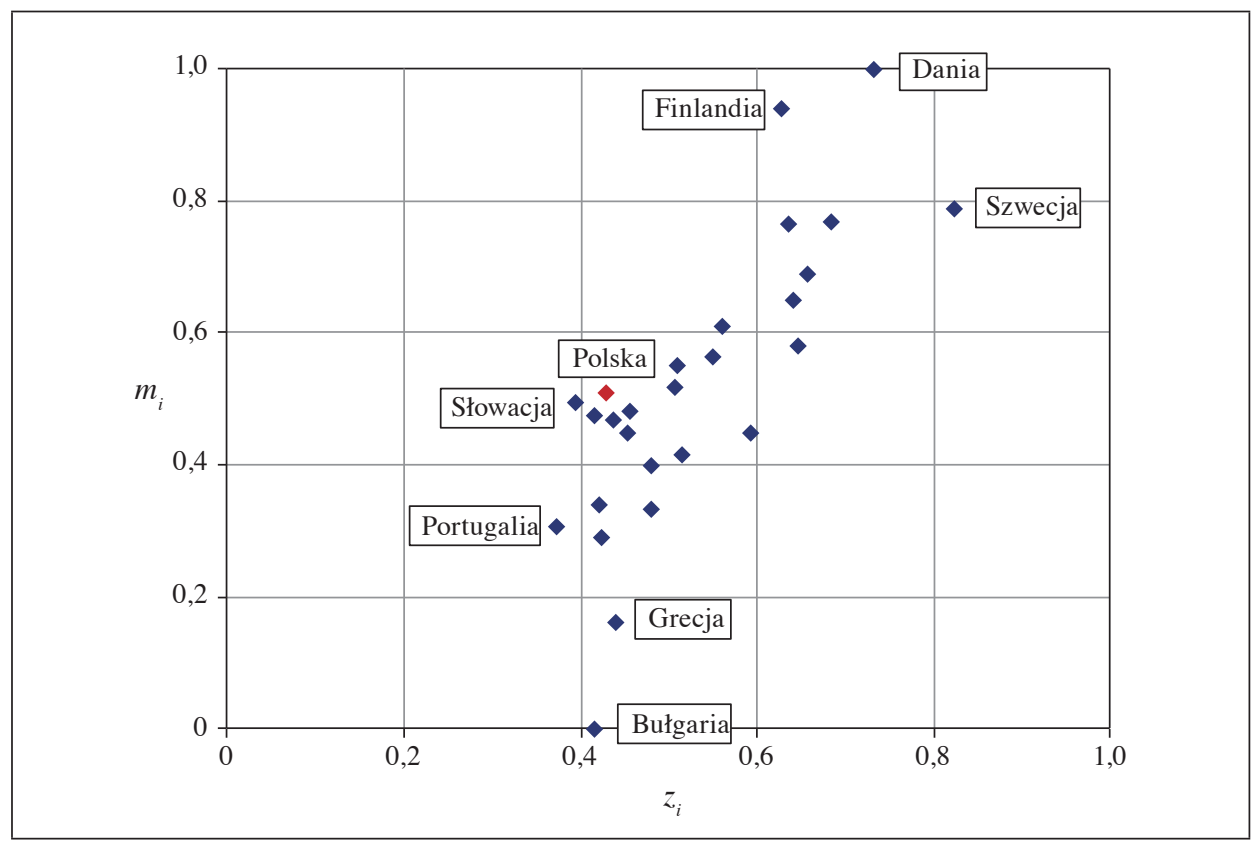

Rys. 2. Porównanie wartości zmiennej syntetycznej i wartości miary rozwoju dla poszczególnych krajów

Źródło: obliczenia własne.

Na podstawie analizy rozrzutu punktów na rys. 2 można zaobserwować, że generalnie wyższym wartościom zmiennej syntetycznej towarzyszą wyższe wartości miary rozwoju, co oznacza w większości przypadków zgodność ocen obiektywnych z subiektywnymi odczuciami osób w wieku niemobilnym. Najkorzystniejsza 
sytuacja występuje w krajach skandynawskich, przy czym warto zwrócić uwagę, że Szwedzi są mniej usatysfakcjonowani niż Finowie czy Duńczycy, chociaż na podstawie wartości zmiennej syntetycznej można stwierdzić, że Szwecja jest krajem najbardziej przyjaznym osobom w rozpatrywanym wieku. Niekorzystna sytuacja występuje natomiast w Bułgarii i Grecji, w których niezadowolenie jest wyższe niż mogłoby to wynikać z obiektywnej oceny sytuacji. Ciekawa jest sytuacja w przypadku Portugalii, w której, przeciwnie niż w wymienionych wyżej krajach, relatywnie odczucia są lepsze niż obiektywny ogląd sytuacji. Osoby w wieku niemobilnym w Polsce charakteryzuje średnie na tle innych krajów zadowolenie z własnej sytuacji, co jednak warto podkreślić, przy relatywnie znacznie gorszej sytuacji ocenianej na podstawie zmiennej syntetycznej (czerwony punkt na wykresie).

Podsumowując wyniki badań, należy zauważyć bardzo dobrą sytuację osób w wieku niemobilnym w krajach skandynawskich. Świadczą o tym zarówno wysokie wartości zmiennej syntetycznej zbudowanej na podstawie zmiennych przyjętych jako obiektywnie obrazujące stan w obszarach ważnych dla funkcjonowania w społeczeństwie, jak i bardzo wysokie wartości miary rozwoju zbudowanej na podstawie subiektywnych odczuć respondentów z tej grupy wiekowej. Rozwiązania przyjęte w Danii, Finlandii czy Szwecji powinny być zatem traktowane jako dobre praktyki. Nie chodzi tutaj o wielkość środków przeznaczanych na wsparcie różnych grup na rynku pracy (wskazane kraje należą do najbogatszych w Unii Europejskiej), ale o całokształt działań zapewniających jednostkom możliwość rozwoju. Przykład Niemiec czy Włoch, a więc krajów o znacznie wyższym PKB na mieszkańca niż średnia unijna, pokazuje, że stosowane w tych krajach rozwiązania dotyczące osób w wieku niemobilnym nie są dobrze odbierane (bardzo niskie miejsce w rankingu według miary rozwoju, a powyżej średniej według zmiennej syntetycznej).

Wyniki badań można uznać za obiecujące, biorąc pod uwagę możliwości ich pogłębienia. Warto byłoby porównać zaprezentowane w artykule wyniki $\mathrm{z}$ analogicznymi opracowanymi dla całej populacji osób w wieku produkcyjnym. Porównanie takie pozwoliłoby na ocenę sytuacji osób w wieku niemobilnym na tle średniej sytuacji społeczno-gospodarczej w poszczególnych krajach, a tym samym ocenę jakości różnych rodzajów polityki ukierunkowanej na tę grupę wiekową.

\section{Literatura}

Borys T. [1978], Metody normowania cech w statystycznych badaniach porównawczych, „Przegląd Statystyczny”, nr 2.

Foster L., Walker A. [2015], Active and Successful Aging: A European Policy Perspective, „The Gerontologist”, vol. 55, nr 1, https://doi.org/10.1093/geront/gnv002.

Gatnar E., Walesiak M. [2004], Metody statystycznej analizy wielowymiarowej w badaniach marketingowych, Akademia Ekonomiczna we Wrocławiu, Wrocław.

Grabiński T. [1992], Metody taksonometrii, Akademia Ekonomiczna w Krakowie, Kraków. 
Grabiński T., Wydymus S., Zeliaś A. [1989], Metody taksonomii numerycznej w modelowaniu zjawisk społeczno-gospodarczych, PWN, Warszawa.

Hellwig Z. [1968], Zastosowanie metody taksonomicznej do typologicznego podziału krajów ze względu na poziom ich rozwoju oraz zasoby i strukturę wykwalifikowanych kadr, „Przegląd Statystyczny”, nr 4.

Hellwig Z. [1981], Wielowymiarowa analiza porównawcza i jej zastosowanie w badaniach wielocechowych obiektów gospodarczych [w:] Metody i modele ekonomiczno-matematyczne $w$ doskonaleniu zarzqdzania gospodarkq socjalistycznq, red. W. Welfe, PWE, Warszawa.

Kołodziejczyk-Olczak I. [2014], Zarzqdzanie pracownikami w dojrzałym wieku - wyzwania i problemy, Wydawnictwo Uniwersytetu Łódzkiego, Łódź.

Kurkiewicz J., Pociecha J., Zając K. [1991], Metody wielowymiarowej analizy porównawczej w badaniach rozwoju demograficznego, Szkoła Główna Handlowa w Warszawie, Instytut Statystyki i Demografii, Monografie i Opracowania 336, Warszawa.

Kwiatkowska-Ciotucha D. [2002], Ranking branż produkcyjnych w Polsce $w 2000$ r., Ekonometria 9, Prace Naukowe Akademii Ekonomicznej we Wrocławiu, nr 935, Wrocław.

Kwiatkowska-Ciotucha D., Załuska U., Dziechciarz J. [2007], Analiza porównawcza odczuć satysfakcji zawodowej - Polska na tle wybranych krajów Unii Europejskiej, Wydawnictwo Akademii Ekonomicznej we Wrocławiu, Wrocław.

Panek T. [2009], Statystyczne metody wielowymiarowej analizy porównawczej, Szkoła Główna Handlowa w Warszawie, Warszawa.

Prognoza ludności na lata 2014-2050 [2014], GUS, Warszawa.

Rozwiqzania sprzyjajqce aktywnemu starzeniu się w wybranych krajach Unii Europejskiej [2013], red. E. Kryńska, P. Szukalski, Uniwersytet Łódzki, Łódź.

Strahl D. [1990], Metody programowania rozwoju społeczno-gospodarczego, PWE, Warszawa.

Załuska U. [2002], Próba klasyfikacji polskiego sektora produkcyjnego [w:] Ekonometria 9, Prace Naukowe Akademii Ekonomicznej we Wrocławiu, nr 935, s. 209-216, Wrocław.

\section{Comparative Analysis of the Situation of People of Non-mobile Age in EU Countries}

The article presents the results of research aimed at objectively assessing the situation of people of a non-mobile age in the European Union (UE 27) and comparing it with the subjective feelings of respondents from that age group. The focus was on Poland, against the background of other Member States, as well as the search for good practices. The study compared two approaches to assessing the age group. The first was based on objective data illustrating the situation in areas of particular social importance. The second approach relied on subjective assessments of the satisfaction of 50-64 year-olds. Taxonomic methods were used. The study's results made it possible to identify those countries that may be considered the friendliest for individuals of non-mobile age and to confront the objectively assessed and subjective perceptions of these people in each country.

Keywords: multivariate comparative analysis, composite indicator, measure of development, people in the non-mobile age. 